\title{
IMPLEMENTASI PROBLEM SOLVING BERORIENTASI HIGHER ORDER THINKING SKILL (HOTS) PADA PEMBELAJARAN IPS SEKOLAH DASAR
}

\author{
Siwi Utaminingtyas \\ Siwiutami66@gmail.com \\ PGSD IKIP PGRI WATES
}

\begin{abstract}
ABSTRAK
Kurikulum 2013 hadir sebagai penyempurna kurikulum sebelumnya yaitu kurikulum KTSP, kurikulum ini diharapkan dapat mengubah pola pikir seorang pendidik dalam mengelola, merencanakan, dan mengembangkan pembelajaran di kelas. Namun, berdasarkan kenyataan di lapangan, pendidik mengalami kesulitan dalam pengemasan pembelajaran IPS, hal ini terlihat dari kegiatan belajar peserta didik yang tidak diarahkan menemukan sebuah konsep namun hafalan semata, pembelajaran berpaku pada buku bukan ke arah mengembangkan kemampuan berpikir kritis. Untuk itu memerlukan sebuah model pembelajaran yang dapat mengembangkan tingkat berpikir tingkat tinggi (Higher Order Thinking Skill) peserta didik, yaitu Model pembelajaran Problem Solving. Penelitian ini bertujuan untuk mengetahui implementasi Problem Solving berorientasi HOTS pada pembelajaran IPS di Sekolah Dasar. Jenis penelitian yang digunakan yaitu studi kepustakaan dengan pendekatan penelitian kualitatif. Teknik pengumpulan data yaitu dengan studi dokumentasi yang dilakukan dengan menganalisis isi dokumen yang berhubungan dengan masalah yang diteliti. Dengan adanya kajian mengenai penelitian ini, dapat dijadikan acuan bagi guru untuk melaksanakan pembelajaran di Sekolah Dasar. Dengan demikian dapat dijadikan sebuah solusi bagi guru untuk mengatasi permasalahan dalam pembelajaran.
\end{abstract}

Kata kunci: Problem Solving, Higher Order Thingking Skill, Pembelajaran IPS SD

\section{IMPLEMENTATION OF PROBLEM SOLVING ORIENTED HIGHER ORDER THINKING SKILL (HOTS) IN SOCIAL LEARNING PRIMARY SCHOOL}

\begin{abstract}
The 2013 curriculum is present as a refinement of the previous curriculum, which is the KTSP curriculum, this curriculum is expected to change the mindset of an educator in managing, planning, and developing classroom learning. However, based on the reality on the ground, educators have difficulty in packaging social studies learning, this can be seen from the learning activities of students who are not directed to find a concept but memorize it, learning is based on books not towards developing critical thinking skills. For this reason, it requires a learning model that can develop students' higher order thinking level, namely Problem Solving. This study aims to determine how the implementation of HOTS oriented Problem Solving in social studies learning in elementary schools. The type of research used is literature study with a qualitative research approach. Data collection techniques namely the documentation study conducted by analyzing the contents of documents related to the problem under study. With the study of this research, it can be used as a reference for teachers to carry out learning in elementary schools. Therefore can be used as a solution for teachers to overcome problems in learning.
\end{abstract}

Keyword: Problem Solving, Higher Order Thingking Skill, Social Learning, Primary School 


\section{PENDAHULUAN}

Menyongsong sebuah kurikulum baru tentunya perlu adanya sebuah perubahan pada pelaksanaan kegiatan pembelajaran di sekolah. Perubahan ini dalam rangka menghadapi pembangunan Abad ke 21 dimana perlu adanya pembaharuan di bidang pendidikan terutama pembaharuan kurikulum, kurikulum 2013 bertujuan membekali warga Indonesia agar memiliki kemampuan hidup kreatif, inovatif, produktif serta berkontribusi dalam kehidupan masyarakat, bangsa, dan bernegara (Kunandar, 2013). Perubahan ini meliputi perubahan persiapan guru mengajar, penyampaian materi pembelajaran, dan menciptakan kegiatan pembelajaran yang bersifat student centered. Duckworth (Prasetya, 2014) student centered memberi kebebasan terhadap peserta didik untuk memperoleh dan mengembangkan pengetahuan. Seorang guru harus lebih produktif, kreatif dan mampu berinovasi dalam pembelajaran, peran guru dalam pembelajaran student centered adalah sebagai fasilitator peserta didik untuk mengembangkan kemampuan berpikir kritis dan kreatif di setiap pembelajaran. Kegiatan pembelajaran dijadikan oleh guru sebagai sarana untuk melatih dan mengembangkan kemampuan berpikir kritis.

Pendidikan adalah kegiatan berupa aktivitas mendidik, yang pada intinya terletak pada proses belajar, dan inti dari proses belajar adalah terletak pada proses kemampuan berpikirnya (Sanusi, 2013). Pendidikan merupakan upaya untuk melatih dan mengembangkan peserta didik untuk berpikir melalui kegiatan pembelajaran. Pembelajaran tidak hanya sekedar menerima sebuah materi pelajaran, namun peserta didik harus ditekankan pada keterampilan berpikir. Berpikir kritis, berpikir tingkat tinggi, pembelajaran dengan saintifik, dan mandiri dalam kegiatan pembelajaran adalah karakteristik dari pembelajaran kurikulum 2013. Untuk mengembangkan kemampuan berpikir itulah maka peserta didik perlu dilatih untuk selalu mengembangkan kemampuan HOTS.

Kurikulum 2013 yang syarat dengan penanaman sikap nilai sosial dan pengembangan kemampuan berpikir tingkat tinggi yang terintegrasi dalam setiap kegiatan pembelajaran, tentunya dalam menghadapi era globalisasi HOTS sangatlah diperlukan dalam menghadapi permasalahan-permasalahan global di era ini, untuk 
itu semenjak dini anak harus dilatih untuk mengembangkan kemampuan berpikir tingkat tinggi sebagai bekal bagaimana kelak mampu bersaing di dunia nyata karena berpikir saja tidak cukup. Peserta didik harus mencari tahu bukan lagi diberitahu oleh guru. Keaktifan peserta didik dalam mencari tahu tentunya membutuhkan proses berpikir yang kreatif dan cerdas. Peserta didik harus terbiasa menggunakan dan memberdayakan kemampuan berpikirnya. Kemampuan berpikir yang kompleks dari setiap permasalahan yang dipecahkan menjadikan peserta didik terbiasa menghadapi permasalahan yang lebih sulit. Disinilah peran dari pembelajaran berorientasi HOTS. Hal ini sejalan dengan Hanifah (2019) menyatakan bahwa kurikulum 2013 harus mengintegrasikan HOTS di setiap pembelajaran, melalui pembelajaran berorientasi HOTS memberikan ruang bagi peserta didik untuk menemukan konsep pengetahuan melalui kemampuan berpikir kritis, berpikir tingkat tinggi dengan melibatkan pembelajaran yang bermakna. Hasil penelitian Waring \& Robinson (2010) menunjukkan pentingnya mengembangkan kemampuan berpikir kritis, yang dapat dilakukan dengan melibatkan pemecahan masalah (problem solving), membuat dugaan, memperkirakan kemung-kinan dan membuat keputusan.

Laily \& Wisudawati, (2015) materi pembelajaran dalam Kurikulum 2013 mensyaratkan kemampuan peserta didik pada tahap metakognitif, jadi tidak hanya sebatas konseptual ataupun faktual namun peserta didik dapat menghubungkan dari beberapa konsep yang ada, mensintesis, memecahkan permasalahan dengan hipotesis dan memilih cara pemecahan yang tepat (analisis), penemuan hal yang baru (mengkreasi), berani beragumen, bekerjasama, dan mengambil keputusan yang tepat dari permasalahan yang ada (evaluasi). HOTS inilah yang mampu menjembatani pengembangan keempat ranah dalam kurikulum 2013, yaitu metakognitif, analisis, mengkreasi, dan evaluasi. Oleh karena itu, disetiap mata pelajaran dalam kurikulum 2013 HOTS sudah diperkenalkan sejak dini di bangku sekolah dasar, dengan harapan peserta didik terbiasa memecahkan permasalahan dan kelak mampu bersaing di era globalisasi.

HOTS merupakan tingkat kemampuan berpikir kognitif yang lebih tinggi yang dikembangkan dari berbagai konsep-konsep, metakognitif, taksonomi pembelajaran, proses pembelajaran yang melibatkan proses penemuan dan pemecahan masalah hingga tahap evaluasi, Saputra (Shoimin, 2014). Model Problem 
Solving atau pemecahan masalah dapat membantu merangsang berpikir peserta didik untuk menyelesaikan suatu permasalahan yang kompleks. Ristiasari, Priyono, \& Sukaesih (2012) menyatakan bahwa problem solving memiliki beberapa kelebihan jika model tersebut diterapkan di kelas, antara lain: melatih kemampuan peserta didik hingga terampil dalam menghadapi dan memecahkan permasalahan, memilih dan menentukan solusi yang tepat dari permasalahan yang diberikan, mengembangkan kemampuan berpikir peserta didik secara kreatif dan inovatif dalam pemecahan masalah, sebagai bekal bagi peserta didik untuk melatih memecahkan permasalahan yang ia hadapi di kehidupan sehari-hari.

Ada empat tujuan pembelajaran IPS, hal ini disampaikan menurut Hadi (Susanto, 2014) antara lain: Pertama, IPS dapat membantu mengenalkan peserta didik dengan lingkungannya, mengingat materi pembelajaran IPS sangatlah luas. Kedua, IPS bukanlah sebuah materi pembelajaran yang sekedar hapalan, teori atau sejarah belaka, namun muatan materi pembelajaran IPS dapat melatih kemampuan berpikir peserta didik. Ketiga, melatih bagaimana bersikap dalam kehidupan seharihari dan peduli terhadap lingkungannya. Keempat, nilai-nilai dalam pembelajaran IPS merupakan nilai-nilai yang tumbuh dan berkembang di lingkungan masyarakat seperti nilai kepercayaan, nilai pergaulan, menghargai perbedaan, taat terhadap hukum dan pemerintahan.

Output pembelajaran dengan model pemecahan masalah tidak ditujukan untuk perolehan pengetahuan atau teori belaka, namun bagaimana caranya agar dari pengetahuan bidang studi yang dipelajari oleh peserta didik dapat dimanfaatkan untuk menghadapi hal-hal baru atau situasi baru di kehidupan seharihari, IPS dapat membentuk peserta didik dalam berbagai macam kemampuan prososial dan demokrasi proaktif, tanggung jawab, dan budi pekerti luhur yang diperlukan dalam masyarakat, Hestiningsih dan Sugiharsono (Chilcoat \& Ligon, 2015). Model Problem Solving ini sangat sesuai dengan karakteristik pembelajaran IPS. Ilmu Pengetahuan Sosial dalam kurikulum 2013 terintegrasi ke dalam beberapa pembelajaran yang lain serta terintegrasi ke dalam cabang ilmu sosial dengan menyuguhkan permasalahan sehari-hari. Permasalahan dalam pembelajaran IPS sangatlah luas, permasalahan ini dapat mencakup beberapa hubungan di dalamnya, seperti hubungan antar manusia dengan yang lain, hubungan manusia dengan 
lingkungan tempat tinggalnya, hubungan manusia dengan lembaga kelompok ataupun antar bangsa, Rosardi (2013).

Berdasarkan kenyataan di lapangan, masih terdapat kelemahan dalam pembelajaran IPS, yaitu 1) pembelajaran kurang efektif hal ini disebabkan karena kuatnya dominasi guru di dalam kelas, sehingga pembelajaran menjadi monoton dan siswa bergantung penuh pada guru. 2) selama pembelajaran siswa pasif, siswa kurang berpartisipasi dalam pembelajaran. 3) selain permasalahan di atas, siswa kurang diarahkan untuk berpikir kritis, siswa tidak diarahkan menemukan sebuah konsep namun hafalan semata, pembelajaran berpaku pada buku bukan ke arah mengembangkan kemampuan berpikir kritis.

Berangkat dari ditemukannya beberapa permasalahan dalam pembelajaran IPS, maka betapa pentingnya pengemasan pembelajaran dengan Problem Solving berorietasi HOTS pada pembelajaran IPS, untuk itu perlu adanya kajian mengenai hal tersebut. Dengan adanya kajian mengenai problem solving, higher order thinking skills dan pembelajaran IPS di sekolah dasar, maka kajian ini dapat dijadikan salah satu cara pengemasan pembelajaran yang dapat diterapkan oleh para guru di kelas, dengan melihat ruang lingkup dan keterkaitan antara ketiga hal tersebut dapat dijadikan pandangan bagi guru bahwa guru harus menciptakan pembelajaran bermakna di kelas dengan cara mengubah mindset pembelajaran IPS yang identik dengan hafalan tentang materi atau sejarah menjadi keterlibatan konsep, proses, dan berpikir tingkat tinggi. Guru dapat mengembangkan pembelajaran yang sesuai dengan pembelajaran IPS. Oleh karena itu, penulis ingin mengkaji lebih dalam mengenai penerapan Problem Solving berorientasi Higher Order Thinking Skill dalam pembelajaran IPS Sekolah Dasar.

\section{METODE PENELITIAN}

Jenis penelitian yang digunakan adalah studi kepustakaan (Library Research) dengan pendekatan penelitian kualitatif. Studi pustaka merupakan kegiatan mengumpulkan data penelitian yang sesuai/ relevan dengan topik atau permasalahan selaku objek penelitian tanpa terjun ke lapangan. Ciri dari penelitian ini adalah peneliti langsung berhubungan dengan teks atau naskah, data kepustakaan bersifat tetap dan siap pakai. Data pustaka pada umumnya adalah data sekunder atau pendukung sehingga peneliti mendapatkan data bukan dari data 
orisinil atau tangan pertama di lapangan, tetapi diperoleh dari tangan kedua. Selain itu, kondisi dari data kepustakaan ini tidak dibatasi oleh ruang dan waktu (Mestika, 2014).

Teknik pengumpulan data dalam penelitian ini adalah studi dokumentasi, yaitu teknik pengumpulan data dengan cara menganalisi isi dokumen yang berkaitan dengan masalah yang diteliti. Menurut Gunawan (2013) analisis dilakukan dengan cara membandingkan dan memadukan dokumen-dokumen untuk membentuk suatu hasil kajian yang sistematis. Sumber data yang digunakan yaitu berupa buku dan jurnal terkait dengan topik yang dipilih.

\section{HASIL PENELITIAN DAN PEMBAHASAN}

\section{Kurikulum 2013 Berbasis Higher Order Thingking Skill}

Dalam menyambut era globalisasi yang penuh tantangan, Pemerintah perlu melakukan suatu inovasi terutama dalam pelaksanaan pendidikan di Indonesia. Pendidikan dijadikan tujuan utama inovasi dalam menyambut era globalisasi, dengan adanya pendidikan seseorang mempunyai bekal ilmu, kemampuan, dan sumber daya yang matang dalam menghadapi era yang penuh persaingan. Inovasi yang dilakukan oleh Pemerintah di bidang pendidikan adalah pembaharuan kurikulum baru yaitu kurikulum 2013. Sebuah kurikulum baru lahir sebagai pelengkap dan penyempurna kurikulum sebelumnya. Penyempurnaan kurikulum ini dilakukan guna meningkatkan mutu pendidikan di Indonesia. Salah satu penyempurnaan yang tampak yaitu di ranah pembelajaran, dimana di kurikulum sebelumnya hanya mengembangkan ranah kognitif saja, namun di kurikulum 2013 ini menekankan ke 3 ranah secara seimbang yaitu ranah kognitif, afektif, dan psikomotorik.

Hidayat (2013: 128) menyatakan bahwa ada beberapa perubahan proses pembelajaran dalam Kurikulum 2013, antara lain : Pertama, proses pembelajaran harus mencakup 5 M yaitu Menanya, Mengamati, Menalar, Mencoba, dan Mengkomunikasikan. Kedua, pembelajaran dapat tidak hanya dilaksanakan di dalam kelas. Hal ini bertujuan agar pembelajaran menyenangkan, tidak terkesan monoton, dan pembelajarannya menjadi lebih nyata karena objek pembelajaran dapat diamati secara langsung oleh peserta didik. Ketiga Guru berperan sebagai fasilitator bukan satu-satunya sumber belajar, peserta didik dapat belajar dari internet, video, 
maupun study lapangan. Keempat, pembelajaran dalam kurikulum 2013 mengembangkan kemampuan peserta didik untuk berpikir tingkat tinggi (Higher Order Thinking Skills).

Menurut Heong, et al (2011) higher order thinking is using the thinking widely to find new challenge. Higher order thinking demands someone to apply new information or knowledge that he has got and manipulates the information to reach possibility of answer in new situation. HOTS memberikan peluang bagi siswa untuk mengembangkan pemikiran secara luas untuk menemukan tantangan baru. Pemikiran tingkat tinggi menuntut seseorang untuk menerapkan informasi atau pengetahuan baru yang dia dapatkan dan memanipulasi informasi untuk mencapai kemungkinan jawaban dalam situasi baru. Inilah yang menjadi tugas seorang guru selaku seniman di kelas. Guru harus mampu menghidupkan kelas, disamping dituntut ketiga aspek hasil belajar dalam Kurikulum 2013 terpenuhi (kognitif, afektif, dan psikomotorik), guru juga mampu membiasakan peserta didiknya untuk berpikir kritis, analitis, dan kreatif.

Berdasarkan kenyataan di lapangan, kelemahan dalam pembelajaran IPS yang pertama adalah guru kurang mengembangkan kemampuan berpikir kritis siswa. Siswa tidak diarahkan menuju sebuah penemuan proses maupun konsep, namun teori hapalan semata. Hal ini tentunya berdampak pada kemampuan peserta didik dalam mengatasi permasalahan yang dia hadapi. Puspitasari (2016: 558) menyatakan bahwa seorang guru hendaknya mengembangkan dan melatih keterampilan berpikir tingkat tinggi dalam kehidupan sehari-hari, karena pada hakikatnya setiap peserta didik akan mengalami suatu permasalahan dalam kehidupan sehari-hari. Alasan inilah maka HOTS diperkenalkan kepada peserta didik sejak dini, dengan terbiasa mengerjakan soal dengan berpikir tingkat tinggi maka anak akan terbiasa memecahkan permasalahan bahkan permasalahan yang terbilang sulit. Pembelajaran tidak hanya melibatkan proses "berpikir" saja namun melibatkan kemampuan berpikir tingkat tinggi. Konsep pembelajaran HOTS dapat diamati pada tabel di bawah ini :

Tabel 1. Konsep Dasar Higher Order Thingking Skills

$\begin{array}{cc}\text { Taksonomi Kognitif Bloom } & \text { Taksonomi Bloom Revisi } \\ \text { Original (1956) } & \text { Anderson \& Krathwohl } \\ & \text { (2001) }\end{array}$

Keterangan

90 | Jurnal Ilmiah Pendidikan Dasar Vol. VII No. 2 Juli 2020 


\begin{tabular}{ccc}
\hline Knowledge (Pengetahuan) & Remember (mengingat) & Lower Order \\
Comprehension (pemahaman) & Understand (memahami) & Thingking Skills \\
\hline Application (penerapan) & Apply (mengaplikasikan) & \\
Analysis (analisis) & Analize (menganalisis) & Higher Order \\
Synthesis (sintesis) & Evaluate (mengevaluasi) & Thingking Skills \\
Evaluation (evaluasi) & Create (mencipta) & \\
\hline
\end{tabular}

Dari tabel di atas dapat diamati bahwa hasil belajar dari pembelajaran dengan penerapan HOTS dimulai dari tahap menganalisis (C4), mengevaluasi (C5), dan mencipta (C6). Pembelajaran dengan HOTS tidak hanya sekedar mengingat atau mememahami saja, namun lebih dari proses berpikir rata-rata. Apabila hal ini diterapkan pada pembelajaran, tentunya memberikan manfaat yang besar bagi peserta didik. Hal ini sesuai dengan pendapat Abosalem (2016) bahwa "Educators consider higher-order thinking skills as high order thinking that occurs when the student obtains new knowledge and stores it in his memory, then this knowledge is correlates, organized, or evaluated to achieve a specific purpose. These skills have to include sub-skills such as analysis, synthesis and evaluation, which are the highest levels in Bloom's cognitive taxonomy". Keterbiasaan peserta didik terhadap pembelajaran yang dikemas dengan pemberian permasalahan yang melibatkan kemampuan berpikir tingkat tinggi (analize, evaluate, dan create), sangat bermanfaat untuk diterapkan dalam kehidupan sehari-hari peserta didik sehingga mampu menyelesaikan permasalahan dengan baik karena peserta didik sudah terbiasa menelaah suatu permasalahan dan mampu memecahkan permasalahan dengan pengetahuannya.

\section{Model Problem Solving}

Melihat kelemahan pembelajaran IPS di atas, terdapat faktor-faktor lain yang menyebabkan pembelajaran IPS ini sulit dipahami oleh peserta didik. Pembelajaran yang kurang efektif dengan kuatnya dominasi guru di dalam kelas, menyebabkan pembelajaran menjadi monoton dan siswa bergantung penuh pada guru. Seorang pendidik diharapkan selalu memiliki motivasi dan semangat dalam memperbaharui cara mengajar. Hal ini sependapat dengan Sinabariba (2017) guru yang mampu mengelola program belajar mengajar adalah guru yang kompeten. Pengelolaan disini bukan berarti kemampuan guru dalam membuka menutup pelajaran atau menyampaikan materi pembelajaran kepada peserta didik, namun guru harus 
mampu mengemas pembelajaran sehingga peserta didik dapat mengembangkan kemampuan berpikirnya. Proses belajar mengajar di dalam kelas akan lebih bermakna jika seorang guru terlebih dahulu mempersiapkan materi sebelumnya. Materi pembelajaran yang seperti apa, dikemas seperti apa, disampaikan seperti apa haruslah sudah dipersiapkan oleh guru sebelumnya. Selain persiapan materi yang mau diajarkan, guru yang akan mengajar juga harus mengetahui karakteristik model pembelajaran yang sesuai untuk materi yang akan diajarkan kepada siswa. Penggunaan model pembelajaran yang efektif akan memudahkan guru dalam mengajar. Kegiatan pembelajaran juga akan menyenangkan bagi guru maupun peserta didik.

Joyce \& Weil (Rusman, 2011) model pembelajaran adalah suatu langkah/ sintaks yang dikembangkan guru yang digunakan untuk merancang kegiatan pembelajaran dan membimbing pembelajaran di kelas. Dari pengertian tersebut dapat digaris bawahi bahwa sebuah model pembelajaran sangatlah penting dalam kegiatan pembelajaran harian, bagi guru sebuah model pembelajaran dapat dijadikan suatu pedoman langkah-langkah pembelajaran dan sebagai variasi penyampaian materi pembelajaran guna tercapai tujuan pembelajaran. Guru dapat mengasah kemampuan berpikir peserta didiknya dengan beberapa sentuhan di kelas, sentuhan disini tentunya adalah kreatifitas Guru dalam mengelola kelas. Salah satunya guru dapat menerapkan beberapa model pembelajaran yang tepat agar "pembiasaan HOTS" ini dapat berjalan. Guru memilih model dimana peserta didik dapat mengembangkan kemampuan berpikir melalui penyelesaian permasalahan nyata yang dipecahkan bersama teman di kelasnya. Model pembelajaran tersebut adalah Model Problem Solving.

Problem Solving merupakan model pembelajaran yang menerapkan pendekatan saintifik. Menurut Permendikbud No.103 Tahun 2014 menyatakan bahwa pembelajaran saintifik terdiri atas beberapa langkah yang terkenal dengan semboyan $5 \mathrm{M}$, yaitu mengamati (observing), menanya (questioning), mencoba (experimenting), menalar (associating), dan mengkomunikasikan (communication). Djamarah (2014) secara operasional langkah-langkah pembelajaran dengan model Problem Solving antara lain :

1. Guru mengkondisikan peserta didik ke dalam kelompok kecil 
2. Guru membagikan LKPD, dimana di dalam LKPD ini peserta didik dituntun untuk memecahkan permasalahan secara berkelompok.

3. Peserta didik mencari keterangan dari berbagai sumber untuk memecahkan permasalahan. Sumber ini bisa berasal dari buku, internet, artikel secara berkelompok.

4. Peserta didik membuat hipotesis/ dugaan sementara dari permasalahan yang diberikan guru.

5. Peserta didik melakukan uji kebenaran jawaban sementara yang dibuat. Peserta didik berusaha memecahkan permasalahan sehingga jawaban sementara tersebut diyakini sudah sesuai.

6. Secara berkelompok, peserta didik membuat kesimpulan atas jawaban-jawaban dari permasalahan.

7. Peserta didik mempresentasikan hasil diskusi kelompok ke depan kelas.

Melihat langkah-langkah pembelajaran di atas, dapat diamati bahwa model pembelajaran Problem Solving sudah mengandung kesesuaian dengan pembelajaran saintifik seperti disyaratkan dalam Kurikulum 2013. Proses Mengamati, Menanya, Menalar, Mencoba, dan Mengkomunikasikan (5M) sudah terpenuhi. Ada hubungan yang sangat erat antara berpikir kritis dengan model pemecahan masalah dan pendekatan ilmiah. Oleh karena itu keterampilan berpikir kritis dapat dikembangkan melalui metode pembelajaran yang berorientasi pada pendekatan ilmiah. Hal ini tentunya sangat cocok dengan prinsip pembelajaran HOTS, dimana pembelajaran tidak hanya menerima sebuah materi, namun peserta didik harus aktif, berpikir kritis, kreatif, dan mengembangkan kemampuan berpikirnya melalui pemecahan masalah.

\section{Implementasi Problem Solving Berorientasi HOTS dalam Pembelajaran IPS Sekolah Dasar}

Melihat keterkaitan prinsip model Problem Solving berorientasi HOTS dengan ciri-ciri, tujuan, dan ruang lingkup Pembelajaran IPS di Sekolah Dasar, maka sebagai seorang guru tentunya dapat diterapkan dan dikembangkan di kelas. Keterampilan pemecahan masalah ini dapat diasah sejak dini melalui pembelajaran-pembelajaran dengan mode pemberian masalah sebagai inti pembelajaran. IPS bukan 
pembelajaran yang menekankan pada hafalan suatu materi atau konsep, namun sangat berkaitan dengan kehidupan sehari-hari dan lingkungannya dimana membutuhkan pemikiran yang kritis, analitis, dan kreatif. Sehubungan dengan itu maka perlu adanya suatu model pembelajaran yang mendukung untuk ketercapaian tujuan pembelajaran IPS. Disinilah keterkaitan yang sangat terlihat IPS dalam kurikulum 2013 perlu dikemas dengan model Problem Solving berorientasi HOTS.

Problem Solving yang selalu menggunakan masalah nyata dalam kehidupan (autentik) selaras dengan tujuan dari pembelajaran IPS itu sendiri yang selalu berkaitan dengan kehidupan sehari-hari dan lingkungannya. Model pembelajaran berbasis masalah memberikan ruang pada peserta didik untuk mengembangkan kemampuan berpikir kritis, melatih menyelesaikan permasalahan secara berkelompok, dan melatih bekerja sama. Tentunya tidak sembarang masalah yang bisa diangkat ke dalam kelas, pemilihan masalah dalam pembelajaran dengan Problem Solving disesuaikan dengan kompetensi dasar, tujuan pembelajaran, dan materi pembelajaran.

Keterkaitan antara model Problem Solving berorientasi HOTS dengan pembelajaran IPS juga dapat diamati dari implementasi penerapan dalam proses pembelajaran. Dalam kegiatan pembelajaran seorang guru perlu merancang dan melaksanakan kegiatan pembelajaran yang memungkinkan peserta didiknya dapat mengkonstruk pemikiran sendiri untuk memecahkan permasalahan atau mencari solusi dengan mengembangkan kemampuan berpikir tingkat tinggi (Higher Order Tinking Skill) dan sesuai dengan sintaks Model Problem Solving. Sebagai contoh peneliti mengembangkan implementasi Problem Solving dalam pembelajaran dengan berorientasi Higher Order Tinking Skill (HOTS) terlihat dalam Tema 1 Subtema 3 pembelajaran 1 Kelas 6 Kurikulum 2013 dengan berpedoman pada sintaks menurut Djamarah (2014: 137). Adapun implementasinya dapat dilihat dari langkah-langkah pembelajaran sebagai berikut:

a. Peserta didik dibagi ke dalam kelompok-kelompok belajar, 4 - 5 kelompok (Fase 1)

b. Peserta didik mengingat kembali materi di subtema sebelumnya tentang "negara-negara di Asia Tenggara" dengan menempelkan plastisin di papan yang sudah disediakan. 


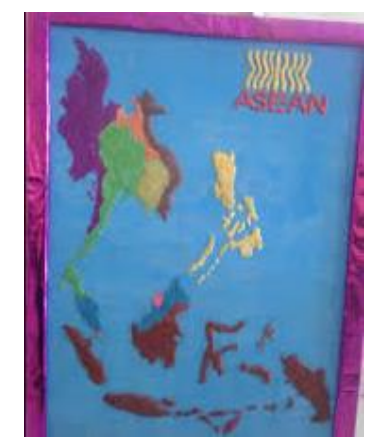

\section{Gambar 1. Peta Asia Tenggara}

c. Siswa bersama guru melakukan tanya jawab tentang ibu kota negara-negara di Asia Tenggara, bahasa negara, lagu kebangsaan, dan keadaan alam di negara negara di Asia Tenggara yang sudah dipelajari pada pertemuan sebelumnya.

d. Guru menayangkan sebuah video tentang keadaan sosial dan geografis negara negara di Asia Tenggara

e. Guru dan siswa melakukan tanya jawab tentang informasi yang didapat dari video.

f. Guru membagikan LKS dan menjelaskan langkah langkah diskusi kelompok. (Fase 2)

g. Guru menyajikan permasalahan sosial yang ada di negara negara Asia Tenggara

8. Setiap kelompok untuk mendiskusikan permasalahan dengan pengetahuan dan keterampilan awal yang mereka miliki setelah melihat video. (Fase 3 )

9. Peserta didik mengerjakan LKS yang berisi permasalahan permasalahan yang dihadapi di negara-negara kawasan Asia Tenggara, siswa didorong untuk menemukan sebuah konsep berdasarkan permasalahan.

10. Peserta didik mengolah informasi secara berkelompok dan mendiskusikan masalah dengan pengetahuan dan keterampilan awal yang dimiliki serta menyusun hipotesis. (Fase 4)

11. Peserta didik menguji cobakan kebenaran jawaban, dengan mengkaitkan kembali permasalahan dan solusi pemecahan masalah. (Fase 5)

12. Guru memantau kerja peserta didik dan mendorong peserta didik untuk memecahkan permasalahan dan menyimpulkan hasilnya. (Fase 6)

13. Peserta didik mempresentasikan hasil diskusi kelompok ke depan kelas. (Fase 7)

14. Guru bersama peserta didik melakukan refleksi pembelajaran

15. Guru memberikan penguatan dan pesan moral. 
Problem Solving berorientasi Higher Order Thinking Skill (HOTS) merupakan pembelajaran pemecahan masalah yang dikemas dalam bentuk kerja kelompok dan diskusi. Hal ini dapat melatih dan mengembangkan kemampuan peserta didik untuk berpikir lebih kritis dan kreatif, memecahkan permasalahan dengan realistis, dan dapat membiasakan para peserta didik untuk terampil dalam memecahkan masalah. Dengan adanya kajian tentang implementasi Problem Solving berorientasi Higher Order Thinking Skill (HOTS) pada pembelajaran IPS dapat dijadikan sebagai acuan bagi guru dalam mengembangkan pembelajaran di kelas, pengemasan pembelajaran saintific dengan model Problem solving bertujuan agar ranah kognitif, afektif, dan psikomotorik peserta didik dapat tercapai secara seimbang. Dengan demikian dapat menjadi solusi bagi guru untuk mengatasi permasalahan-permasalahan yang dijumpai di kelas.

\section{SIMPULAN}

Model pembelajaran mempunyai peran dan pengaruh yang cukup besar dalam keberhasilan kegiatan belajar mengajar. Kemampuan belajar yang diharapkan dari proses belajar yang dimiliki oleh peserta didik, salah satunya ditentukan oleh ketepatan pemilihan model pembelajaran yang sesuai dengan tujuan pembelajaran. Keberhasilan ketercapaian tujuan pembelajaran inilah ukuran dari keberhasilan seorang guru dalam mengajar, terlebih dalam pelaksanaan kurikulum 2013 yang mengembangkan kemampuan tiga ranah, yaitu kognitif, afektif, dan psikomotorik. Peserta didik harus melalui tahap sebuah penemuan baik itu penemuan sebuah konsep maupun penemuan sebuah gagasan dalam usaha pemecahan permasalahan yang disuguhkan oleh guru, pembelajaran tidak hanya menghafal dan memperoleh materi.

Problem solving (pemecahan masalah) merupakan suatu model pembelajaran yang secara khusus memberikan pelatihan dan mengembangkan kemampuan pemecahan masalah melalui kegiatan pembelajaran. Model pembelajaran problem solving memberikan pengalaman dan pengetahuan kepada peserta didik tentang bagaimana memecahkan suatu masalah dalam kehidupan. Peserta didik belajar berangkat dari masalah dan fakta bukan sekedar konsep pengetahuan semata. Masalah disini tentunya dipilih oleh guru yang disesuaikan 
dengan pencapaian kompetensi dasar dan materi pembelajaran. Keterkaitan antara model Problem Solving berorientasi HOTS dengan pembelajaran IPS juga dapat diamati dari implementasi penerapan dalam proses pembelajaran yang sudah dipaparkan di atas. Sintaks dalam problem solving menggambarkan pemenuhan scientific approach (pendekatan ilmiah) dalam kurikulum 2013, dengan pendekatan ilmiah tentunya dapat lebih mengembangkan kemampuan berpikir kritis peserta didik. Hal ini tentunya sangat cocok dengan prinsip pembelajaran HOTS, dimana pembelajaran tidak hanya menerima sebuah materi, namun peserta didik harus aktif, berpikir kritis, kreatif, dan mengembangkan kemampuan berpikirnya melalui pemecahan masalah.

Dengan adanya kajian mengenai implementasi problem solving berorientasi HOTS pada pembelajaran IPS Sekolah Dasar dapat dijadikan acuan bagi guru untuk melaksanakan pembelajaran di kelas dan dijadikan sebagai salah satu alternatif pengemasan pembelajaran bertipe hafalan seperti pembelajaran IPS. Dengan demikian dapat menjadi solusi bagi guru untu mengatasi permasalahan yang ditemui dalam pembelajaran di kelas.

\section{Daftar Pustaka}

Abosalem. (2016). Assessment techniques and students' higher-order thinking skills. International Journal of Secondary Education, 4(1), 1-11.

Djamarah, S.B. (2014). Strategi belajar mengajar. Jakarta: PT Asdi Mahasatya.

Gunawan, Imam. (2013). Metode penelitian kualitatif: Teori dan praktik. Jakarta: PT Bumi Aksara.

Hanifah, N. (2019). Pengembangan instrumen penilaian higher order thinking skill (HOTS) di Sekolah Dasar. Current Research in Education: Conference Series Journal, 1(1), 1-8.

Heong, Y. M.,Othman, dkk. (2011). The level of marzano higher order thinking skills among technical education students. International Journal of Social and Humanity, 1(2), 121- 125.

Hestiningsih, N., \& Sugiharsono. (2015). Peningkatan kemampuan berpikir kritis peserta didik pembelajaran IPS melalui metode Problem Solving berbantuan media informasi. Harmoni Sosial : Jurnal Pendidikan IPS, 2(1), 71-86. 
Hidayat, S. (2013). Pengembangan kurikulum baru. Bandung: PT Remaja Rosdakarya.

Kunandar. (2013). Penilaian autentik. Jakarta: PT Raja Grafindo Persada.

Laily, N.R., \& Wisudawati, A.W. (2015). Analisis soal higher order thingking skill (HOTS). Kaunia Online, 11(1), 27-39.

Mestika, Z. (2014). Metode penelitian kepustakaan. Jakarta: Yayasan Pustaka Obor Indonesia.

Prasetya, S.P. (2014). Memfasilitasi pembelajaran berpusat pada siswa. Jurnal Geografi, 12(1), 1-12.

Puspitasari, S.D. (2016). Penggunaan metode Problem Solving untuk meningkatkan berpikir tingkat tinggi mapel IPS kelas IV SD Karanggondang. Jurnal Pendidikan Guru Sekolah Dasar, 5(7), 556-564.

Ristiasari, T., Priyono, B., Sukaesih, S. (2012). Model pembelajaran Problem Solving dengan mind mapping terhadap kemampuan berpikir kritis siswa. Unnes Journal Of Biology Education, 1(3), 35-41.

Rosardi, R.G. (2013). Pembelajaran IPS dengan strategi pemecahan masalah untuk meningkatkan kemandirian dan kepedulian siswa. Socia: Jurnal IImu Sosial, (10)1, 21-35.

Rusman. (2011). Model-model pembelajaran mengembangkan profesionalisme guru. Jakarta: PT. RajaGrafindo Persada.

Sanusi, A. (2013). Kepemimpinan Pendidikan: Strategi Pembaruan, Semangat Pengabdian, Manajemen Modern. Bandung: Nuansa Cendekia.

Shoimin, A. (2014). Model pembelajaran inovatif dalam Kurikulum 2013. Yogyakarta: AR-RUZZ Media.

Sinabariba, R.B. (2017). Peranan guru memilih model-model pembelajaran untuk meningkatkan kemampuan menulis puisi. Prosiding Seminar Nasional Pendidikan Dasar Universitas Negeri Medan.

Susanto, A. (2014). Pengembangan pembelajaran IPS di sekolah dasar. Jakarta: Prenadamedia Group.

Waring, S.M. \& Robinson, K. S. (2010). Developing Critical and Historical Thinking Skills in Middle Grades Social Studies. Middle School Journal, 42(1), 22-28. 